\title{
Access to 5,5'-diaryl substituted 4,5,4',5'-tetrahydro[3,3']bi-isoxazolyl 2,2'-dioxides, 4,5,4',5'-tetrahydro[3,3']bi-isoxazolyls and [3,3']bi-isoxazolyls via an initial ring-opening of 3,4-dinitrothiophene ${ }^{1}$
}

\author{
Lara Bianchi, ${ }^{a}$ Carlo Dell'Erba, ${ }^{a}$ Francesco Gasparrini, ${ }^{b}$ Marino Novi, ${ }^{a}$ \\ Giovanni Petrillo, ${ }^{* a}$ Fernando Sancassan, ${ }^{a}$ and Cinzia Tavani ${ }^{a}$ \\ ${ }^{a}$ Dipartimento di Chimica e Chimica Industriale, Università di Genova, Via Dodecaneso 31, \\ I-16146 Genova, Italy, and ${ }^{b}$ Dipartimento di Studi di Chimica e Tecnologia delle Sostanze \\ Biologicamente Attive, Università “La Sapienza”, Piazzale Aldo Moro 5, I-00185 Roma, Italy \\ E-mail:petrillo@chimica.unige.it
}

Dedicated to Professor Domenico Spinelli on his $70^{\text {th }}$ birthday

(received 16 Oct 02; accepted 12 Dec 02; published on the web 20 Dec 02)

\begin{abstract}
By means of an iodide-catalyzed nitrocyclopropane to 4,5-dihydroisoxazoline 2-oxide isomerization, the 1,1'-dinitro-[1,1']bi(cyclopropyl)s 5, deriving from an initial ring-opening of 3,4-dinitrothiophene $\mathbf{1}$, can be stereospecifically converted into the bisnitronates $\mathbf{6}$. From these, successive $\mathrm{N}$-oxide reduction $\left[\mathrm{P}(\mathrm{OMe})_{3} /\right.$ dioxane] and aromatization (DDQ/toluene) provide convenient access to the interesting 4,5,4'5'-tetrahydro[3,3']bi-isoxazolyls 7, and [3,3']biisoxazolyls $\mathbf{8}$, respectively.
\end{abstract}

Keywords: Nitrothiophenes, ring-opening reactions, functionalized nitrobutadienes, cyclic nitronates, isoxazolines, isoxazoles

\section{Introduction}

As part of a long-standing research project on the synthetic exploitability of the highly functionalized building blocks deriving from the ring-opening of nitrothiophenes, ${ }^{2}$ we have recently reported on the cyclopropanation of the 1,4-diaryl-2,3-dinitro-1,3-butadienes 3 (Scheme 1 , steps $c$ and $\left.c^{\prime}\right){ }^{2 b}$ Thus, the employment of defective or excess diazomethane allows one to isolate the (nitrovinyl)-nitrocyclopropanes, 4, and the 1,1'-dinitro[1,1']bi(cyclopropyl)s, 5, respectively: the latter being formed essentially as mixtures of a racemic pair $[(d, l)-5]$ and an optically inactive form (meso-5), whose relative amounts depend on the nature of Ar. ${ }^{2 \mathrm{~b}}$

On the grounds of the well-known nitrocyclopropane- to five-membered cyclic nitronate 
isomerization (Scheme 2, step $d$ ),${ }^{3}$ compounds 4 and 5 represent promising precursors of isoxazoline- (step $e$ ) and/or isoxazole- derivatives (steps $f^{4}$ or $e+f^{\prime}$ ). In particular, the possible access to the [3,3']-bi(heterocycle)s $\mathbf{6}, \mathbf{7}$ or $\mathbf{8}$ from $\mathbf{5}$ is surely appealing, given the limited number of reports on the preparation of such systems ${ }^{5}$ as compared to the large number of papers and reviews devoted to the five-membered 1,2-oxaza ring itself. ${ }^{6-8}$<smiles>O=[N+]([O-])c1cscc1[N+](=O)[O-]</smiles>

1

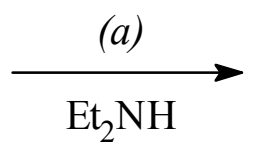

$\mathrm{EtOH}$, r.t.<smiles>CC/N=C/C(=C/NCC)[N+](=O)[O-]</smiles><smiles>O=C(O)[Al]/C=C(\C(=C[Al])[N+](=O)[O-])[N+](=O)[O-]</smiles>

$(E, E)-3$

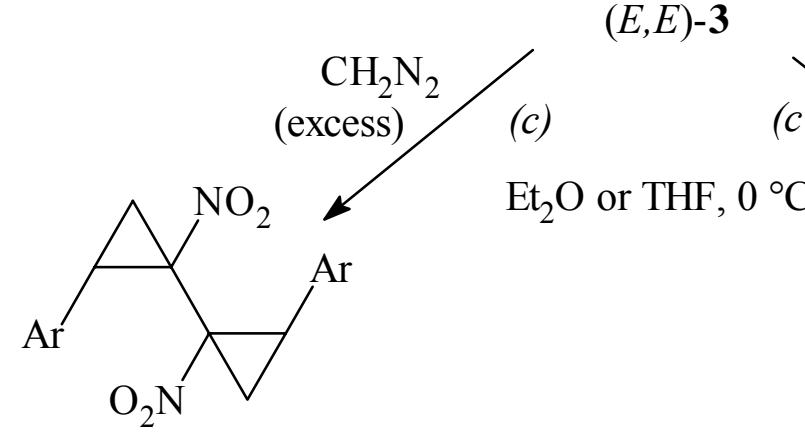

5

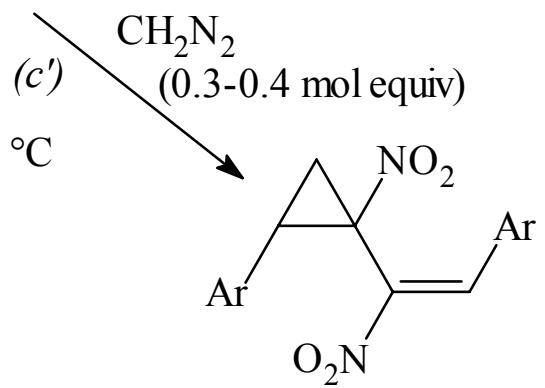

4

\section{Scheme 1}

The interest is surely well justified by the observation that, besides playing a pivotal role in numerous molecules of, e.g., medicinal or agricultural interest, $8 \mathrm{a}, 9$ such a heterocycle is a building block for a variety of polyfunctionalized cyclic or acyclic targets through ring modification and cleavage, $7 \mathrm{c}-\mathrm{e}, 8 \mathrm{a}-\mathrm{d}, 10$ respectively: in the latter case, $\gamma$-amino alcohols, 1,3 -diols, $\alpha, \beta$-unsaturated ketones, and $\beta$-hydroxy ketones are significant examples. 


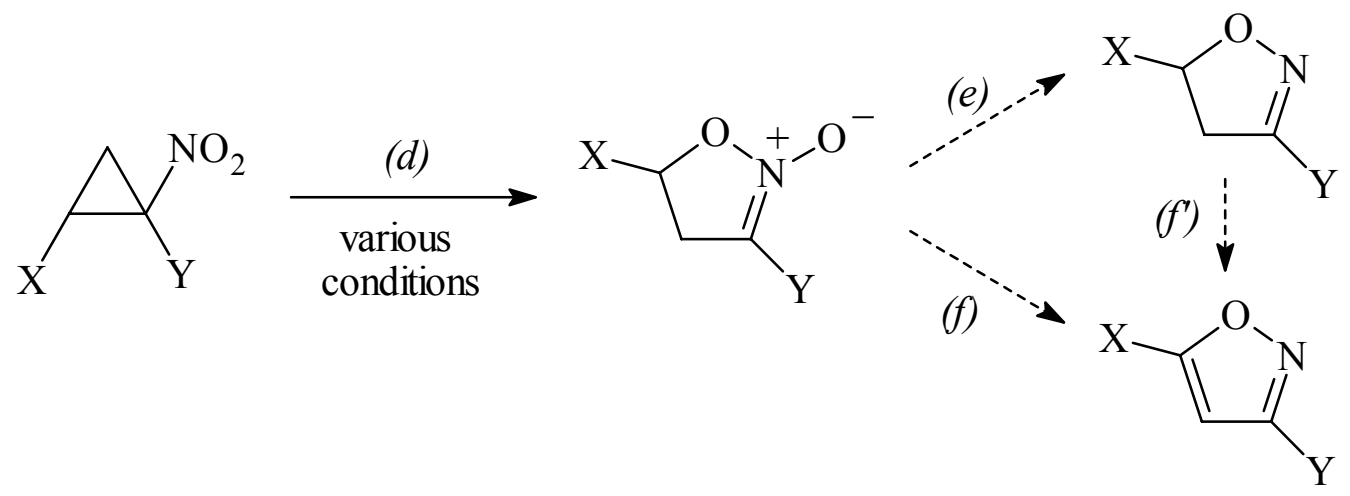

Scheme 2

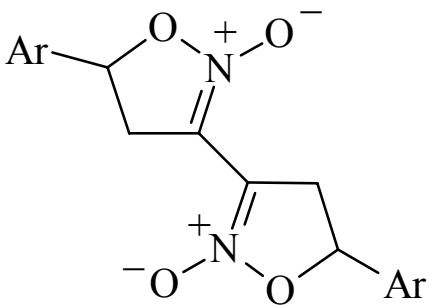

6

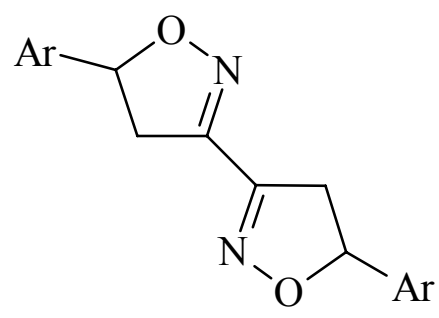

7

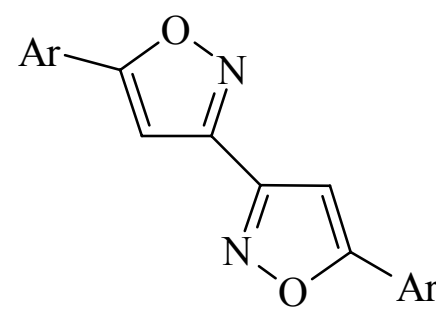

8

We report here some interesting results on the transformation of compounds 5 into 6 and 7 and eventually into 8, which significantly expand the range of applicability of the ring opening of nitrothiophenes to the synthesis of heterocycles and, in particular, add to previous syntheses of isoxazoles via an overall ring-opening / ring-closure route. ${ }^{2 a}, 11$

\section{Results and Discussion}

\section{Isomerization of the nitrocyclopropane moieties of 5: Synthesis of the bisnitronates 6}

As anticipated in the Introduction, the literature offers a few brief reports ${ }^{3}$ on the nitrocyclopropane- to isoxazoline $N$-oxide isomerization, which represents only a secondary, and rather occasional route to such interesting intermediates as the five-member cyclic nitronates. ${ }^{5}$ Besides thermal activation, ${ }^{3 a}$ both electrophilic $\left(\mathrm{BF}_{3} \cdot \mathrm{Et}_{2} \mathrm{O}\right)^{3 \mathrm{a}}$ - or nucleophilic $(\mathrm{NaI})^{3 \mathrm{~b}, \mathrm{c}}$ - catalysis have been employed, in every case ring- expansion reportedly occurring via the selective breakage of the more substituted bond of the cyclopropane ring (cf. Scheme 2).

The thermal isomerization of compounds 5 reported here was found to be excessively slow, leading to complex final mixtures, accompanied by more- or less extensive decomposition. The

use of NaI in DMSO at $70{ }^{\circ} \mathrm{C}$ (Scheme 3) was found to be most convenient for driving the reaction to completion within reasonable times, and minimizing undesired processes. 
Furthermore, we have judged it useful to carry out the reaction separately on the $(d, l)$ - and mesoisomers, in order to gain mechanistic insight into the process from its stereochemical outcome. In this regard, we should remark that, to our knowledge, the literature ${ }^{3}$ lacks substantial mechanistic details on the nitrocyclopropane to cyclic nitronate isomerization.

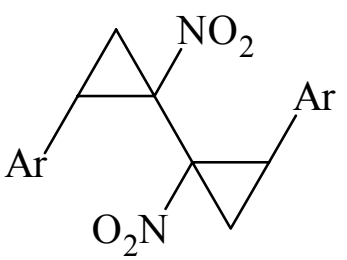

5
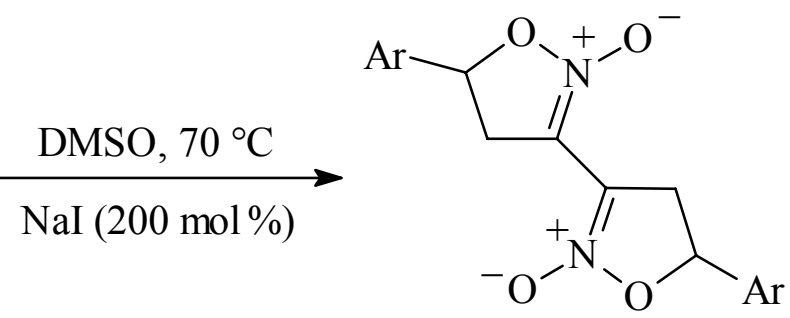

6

\section{Scheme 3}

On the other hand, the conservation in compounds $\mathbf{6}$ of two of the four original stereocenters of 5 enables easy monitoring of the stereochemical course of the isomerization, which is precluded in similar processes on single nitrocyclopropane moieties.

Entries 1 and 2 of Table 1 refer to the $p$-tolyl derivatives $(d, l)$-5a and meso-5a, which have been found to lead stereospecifically to $(d, l)-\mathbf{6 a}$ and meso-6a, respectively. The stereochemistry of the two reaction products, characterized by remarkably different physical properties (such as m.p. or solubility in DMSO), but having practically indistinguishable ${ }^{1} \mathrm{H}$ - and ${ }^{13} \mathrm{C}$ - NMR spectra (see Experimental), has been ascertained by means of stereoselective HPLC analysis on chiral columns (equipped with UV- and CD detectors) (Figures 1 and 2).

Table 1. Results of the 5 to 6 isomerization ${ }^{a}$

\begin{tabular}{ccccc}
\hline Entry & $\mathrm{Ar}$ & $\mathbf{5}$ & Reaction time & $\mathbf{6 ,}$ Yield $(\%)^{\mathrm{b}}$ \\
\hline 1 & $4-\mathrm{MeC}_{6} \mathrm{H}_{4}$ & $(d, l)-\mathbf{5 a}$ & $22 \mathrm{~h}$ & $(d, l)-\mathbf{6 a}, 80$ \\
2 & “ & meso-5a & $22 \mathrm{~h}$ & meso-6a, 87 \\
3 & 1-naphthyl & $(d, l)-5 \mathbf{b}$ & $4 \mathrm{~h}$ & $(d, l)-\mathbf{6 b}, 87$ \\
4 & “ & $m e s o-5 \mathbf{b}$ & $4 \mathrm{~h}$ & meso-6b, 74 \\
5 & 2-thienyl & $5 \mathbf{c}^{\mathrm{c}}$ & $6 \mathrm{~h}$ & $(d, l)-\mathbf{6 c}, 74 ; \mathrm{d}$ meso-6c, 37d \\
\hline
\end{tabular}

a Reactions performed under argon in DMSO at $70{ }^{\circ} \mathrm{C}$, in the presence of anhydrous NaI (200 mol \%); [5] = 0.046M. b Yields are of chromatographically isolated products. ${ }^{\mathrm{c}}$ Mixture of the non-separable $(d, l)$ - and meso- isomers in a 64/36 molar ratio (see Experimental). $\mathrm{d}$ The yield refers to amount of the corresponding stereoisomer in the starting mixture. 


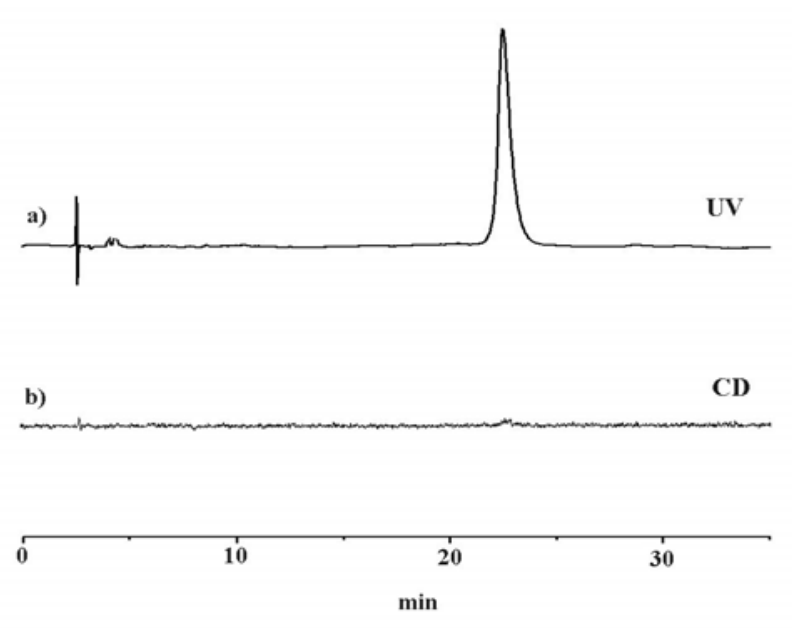

Figure 1. Stereoselective high-performance liquid chromatography of meso-6a: column, $(R, R)$ Whelk-01 (250×4.6 mm I.D.); eluent, 68:29:3 $n$-hexane/CH2Cl2/i-PrOH; flow rate, $1.0 \mathrm{ml} / \mathrm{min}$; $\mathrm{T}, 22{ }^{\circ} \mathrm{C} ; k^{\prime} 18.65$; UV (trace $\left.a\right)$ and $\mathrm{CD}($ trace $b)$ detection at $254 \mathrm{~nm}$.
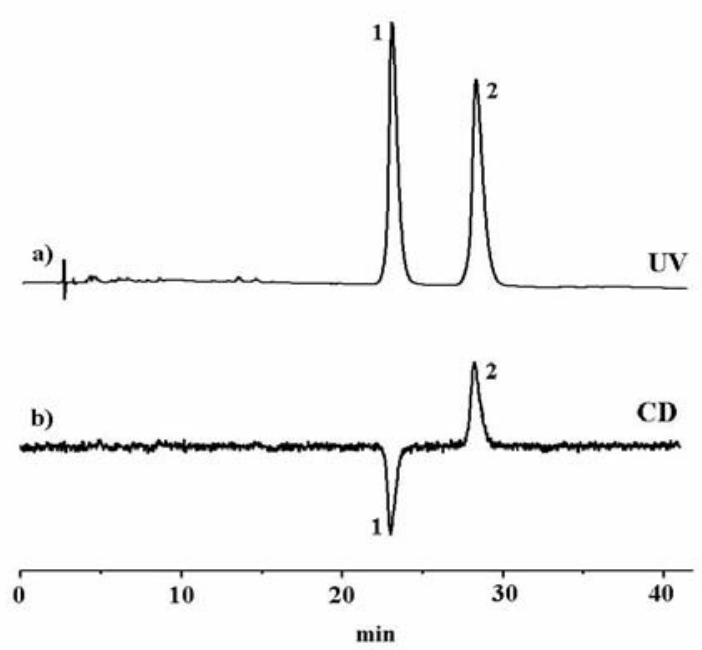

Figure2. Enantioselective high-performance liquid chromatography of $(d, l)$-6a: column, $(R, R)$ Whelk-01 (250×4.6 mm I.D.); eluent, 68:29:3 n-hexane/CH2Cl2/i-PrOH; flow rate, $1.0 \mathrm{ml} / \mathrm{min}$; T, $22{ }^{\circ} \mathrm{C} ; k^{\prime} 18.7, \alpha$ 1.25; UV (trace $a$ )- and CD (trace $b$ )- detection at $254 \mathrm{~nm}$. On-line UV and CD spectra of enantiomers 1 and 2 are also shown.

A similar stereospecificity has been confirmed by chiral chromatography in the case of the 1naphthyl derivatives (5b to $\mathbf{6 b}$ isomerization; entries 3 and 4); consistently, the isomerization of a mixture of the two stereoisomeric 2-thienyl bicyclopropyls 5c, for which any separation of practical significance is precluded, ${ }^{2 b}$ leads to the isolation of two diastereomeric products, with stereochemistry again being assigned (Entry 5) on the grounds of chiral-chromatography results. 
The low isomerization yield for meso-5c can be mainly attributed to the instability observed, in particular, for this stereoisomer.

The observed stereochemical outcome, (a), is undoubtedly of the outmost importance in the perspective, e.g., of a stereoselective synthesis of acyclic polyfunctionalized targets via ring opening of $\mathbf{6}$ or of the isoxazolines 7 therefrom (see below) and, (b), imposes severe restrictions on the reaction mechanism. Thus, the iodide-assisted process, which can be hypothesized (Scheme 4) to occur via double $S_{\mathrm{N}} 2$ nucleophilic displacement at the benzylic chiral carbon atoms (and hence double inversion, with eventual retention of configuration at the two surviving stereocenters of 6), requires that cyclization of the nitronate oxygen onto the postulated intermediate iodonitronate anion $\mathbf{A}^{-}$be faster than iodine exchange, which would lead instead, starting from either $(d, l)-5$ or meso-5, to a mixture of $(d, l)-6$ and meso-6. For the iodide-assisted ring-opening step, alternative mechanisms could be hypothesized which would justify nucleophilic attack onto the more sterically crowded benzylic carbon; anyway, the one advanced here could be rationalized in terms of a $S_{\mathrm{N}} 2$ transition state in which the reacting carbon center bears a residual positive charge. 12

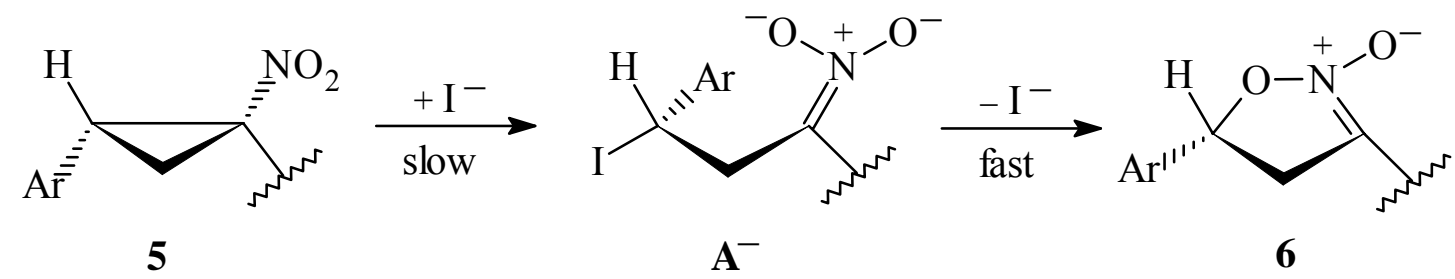

\section{Scheme 4}

As far as the structure of the final products $\mathbf{6 a - c}$ is concerned, the position of the Ar group on the isoxazole ring (i.e., at $\mathrm{C}-5$ ) is guaranteed throughout by the low-field resonance of the methine proton which is, in compounds $\mathbf{6}$, adjacent to the heterocyclic oxygen. Thus, breakage of the more substituted bond of the cyclopropane rings of $\mathbf{5}$ is occurring here, in keeping with the literature reports. ${ }^{3}$ It should also be noted that the spatial distance between the two stereocenters of 6 (which are five bonds away, and therefore not expected appreciably to influence each other) is in agreement with the observed peculiar almost perfect superimposition of the ${ }^{1} \mathrm{H}$ - and ${ }^{13} \mathrm{C}$ NMR spectra of the $d, l$ - and meso- isomers for both $\mathbf{6 a}$ and $\mathbf{6 c}$, with only minimal chemical-shift differences for $\mathbf{6 b}$ (see Experimental).

\section{Reduction of compounds 6 to the 5,5'-diaryl-4,5,4',5'-tetrahydro[3,3']bi-isoxazolyls 7}

The reduction of compounds 6 to the corresponding 4,5,4',5'-tetrahydro[3,3']bi-isoxazolyls 7 has been performed quite efficiently with $\mathrm{P}(\mathrm{OMe})_{3}$ in dioxane at reflux (Scheme 5). The excellent results are collected in Table 2. As expected for a process which should not involve configurational changes at C-5, $(d, l)-\mathbf{6}$ gives a single diastereoisomer, $(d, l)-7$, and meso-6 gives 
meso-7. This has been confirmed by a stereoselective HPLC analysis (Figures 3 and 4, relating to the $p$-tolyl derivatives $7 \mathbf{a})$.

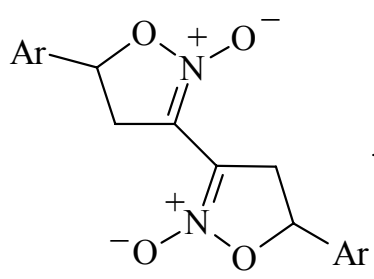

6

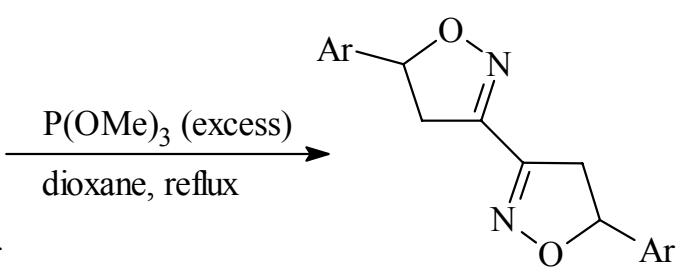

7

\section{Scheme 5}

Table 2. Reduction of compounds 6 to the 5,5'-diaryl-4,5,4',5'-tetrahydro[3,3']bi-isoxazolyls $7^{\text {a }}$

\begin{tabular}{|c|c|c|c|}
\hline Entry & $\mathrm{Ar}$ & 6 & 7, Yield $(\%) b$ \\
\hline 1 & $4-\mathrm{MeC}_{6} \mathrm{H}_{4}$ & $(d, l) \mathbf{- 6 a}$ & $(d, l)-7 \mathbf{a}, 95$ \\
\hline 2 & “ & meso-6a & meso-7a, 91 \\
\hline 3 & 1-naphthyl & $(d, l)-\mathbf{6 b}$ & $(d, l)-7 \mathbf{b}, 86$ \\
\hline 4 & “ & meso-6b & meso-7b, 89 \\
\hline 5 & 2-thienyl & $(d, l)-6 \mathbf{c}$ & $(d, l)-7 \mathbf{c}, 96^{\mathrm{c}}$ \\
\hline 6 & “ & meso-6c & meso-7c, 93 \\
\hline
\end{tabular}

a Reactions performed at reflux in dioxane $(17-24 \mathrm{~h})$ in the presence of excess $\mathrm{P}(\mathrm{OMe})_{3}$. $\mathrm{b}$ Yields of crude products taken up with petroleum ether (b.p. $40-60{ }^{\circ} \mathrm{C}$ ) / methylene chloride, if not otherwise stated. ${ }^{c}$ Yield of chromatographically isolated product.
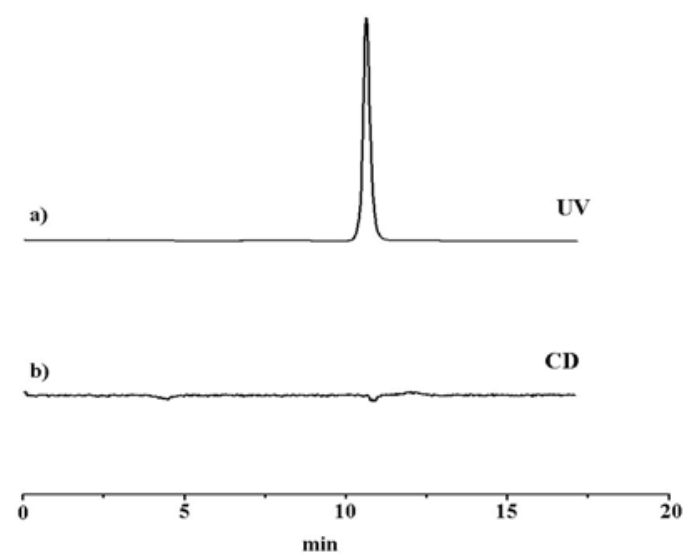

Figure 3. Stereoselective high-performance liquid chromatography of meso-7a: column, $(R, R)$ Whelk-01 (250×4.6 mm I.D.); eluent, 69.7: 29.8: 0.5, $n$-hexane/CH2Cl2/i-PrOH; flow rate, 1.0 $\mathrm{ml} / \mathrm{min}$; T, $22{ }^{\circ} \mathrm{C} ; k^{\prime} 13.5$; UV (trace $\left.a\right)$ and $\mathrm{CD}($ trace $b)$ detection at $254 \mathrm{~nm}$. 

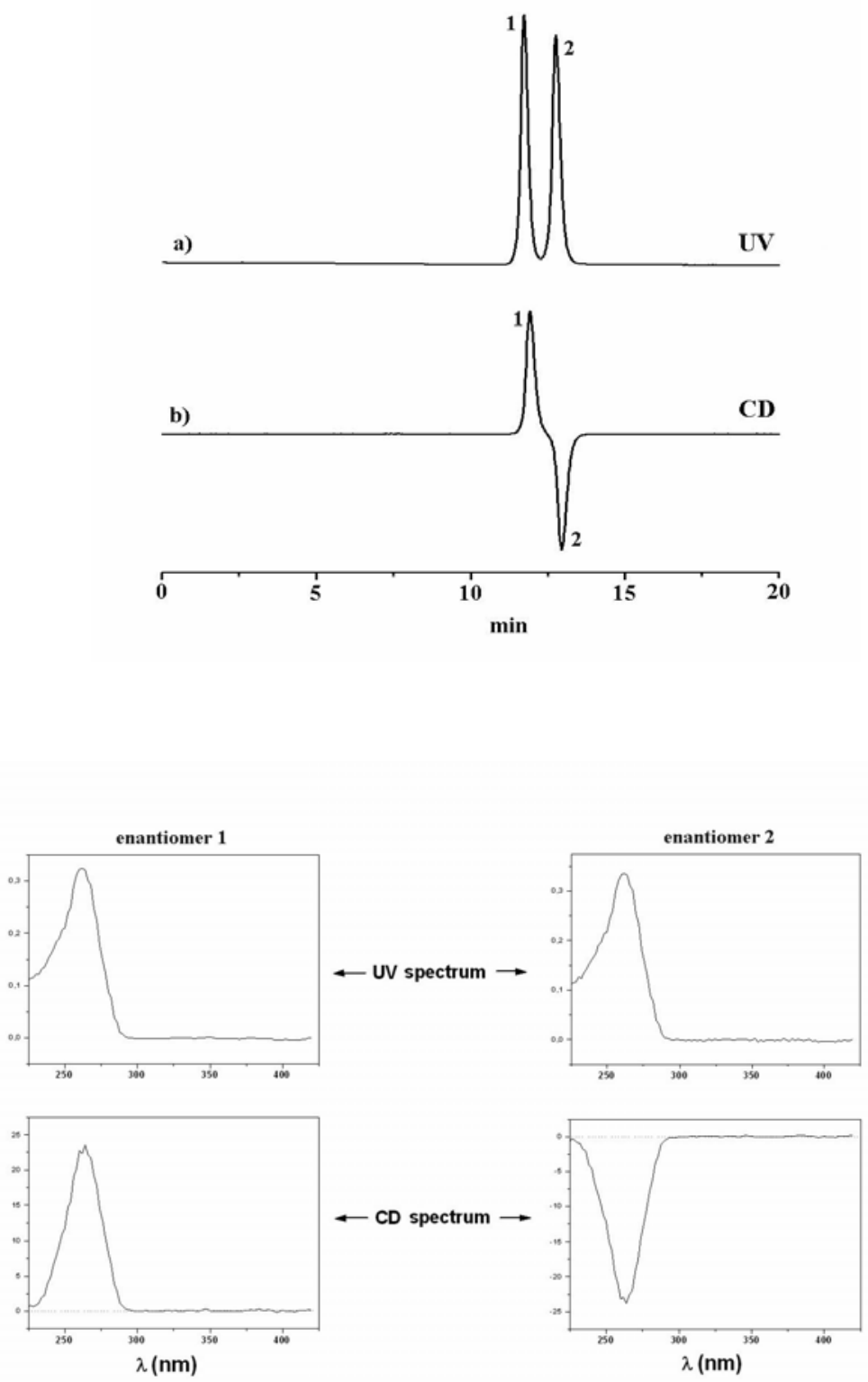

Figure 4. Enantioselective high-performance liquid chromatography of $(d, l)$-7a: column, $(R, R)$ Whelk-01 (250×4.6 mm I.D.); eluent, $69.7: 29.8: 0.5 n$-hexane $/ \mathrm{CH}_{2} \mathrm{Cl}_{2} / i$ - $\mathrm{PrOH}$; flow rate, 1.0 $\mathrm{ml} / \mathrm{min}$; T, $22{ }^{\circ} \mathrm{C} ; k^{\prime} 14.0, \alpha 1.1$; UV (trace $a$ ) and CD (trace $b$ ) detection at $254 \mathrm{~nm}$. On-line UV and CD spectra of enantiomers 1 and 2 are also shown. 


\section{Aromatization of compounds 7 to the 5,5'-diaryl[3,3']bi-isoxazolyls 8 .}

Based on previously reported procedures 11,13 the aromatization of compounds 7 was performed with excess 2,3-dichloro-5,6-dicyano-1,4-benzoquinone (DDQ) in dry toluene at reflux (Scheme 6): different methodologies were less efficient in preliminary tests. Under the conditions employed, prolonged reaction times were required, with some time-depending decomposition of DDQ. Further addition of reactant (see Experimental) was found to be necessary to achieve disappearance (TLC) of substrate: interestingly, in each case, chromatographic separation of the final mixture allowed isolation (Table 3) of a secondary product, identified as the monoaromatization derivative, $\mathbf{9}$. While the effectiveness of the process clearly rests on the excellent overall balance, compounds 9 themselves are interesting "asymmetrized" building blocks for further manipulation.

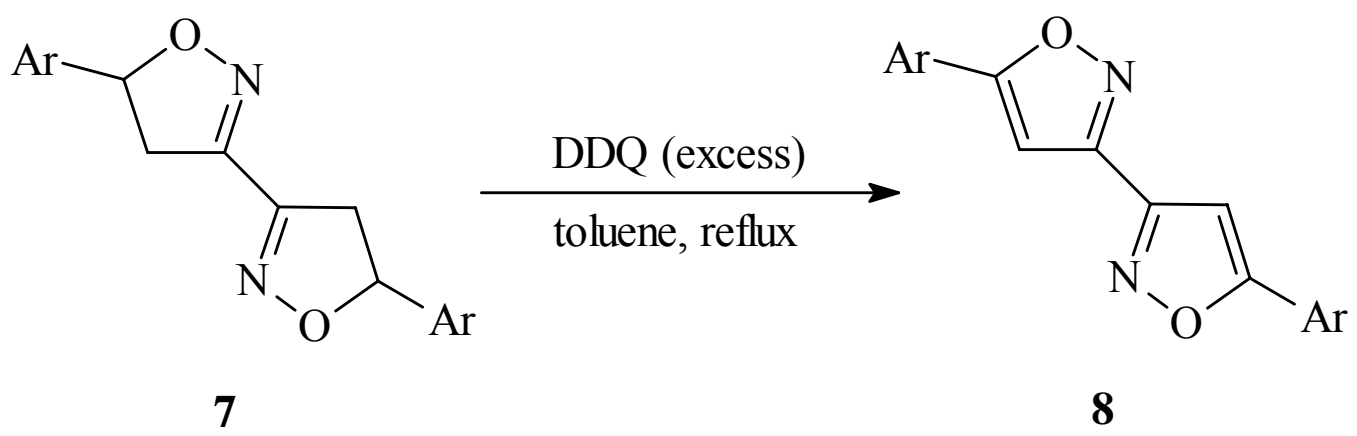

\section{Scheme 6}

Table 3. Results for the aromatization of compounds $7^{\mathrm{a}}$

\begin{tabular}{ccccccc}
\hline Entry & \multirow{2}{*}{$\mathrm{Ar}$} & $\mathbf{7}$ & Reaction time & \multicolumn{4}{c}{ Yield (\%) } \\
\cline { 3 - 7 } & & & $\mathbf{8}$ & $\mathbf{9}$ & $\mathbf{7 c}^{\mathrm{c}}$ \\
\hline 1 & 4- $\mathrm{MeC}_{6} \mathrm{H}_{4}$ & $(d, l)-7 \mathbf{a}$ & $20 \mathrm{~h}$ & 77 & 12 & - \\
2 & “ & meso-7a & $20 \mathrm{~h}$ & 81 & 11 & - \\
3 & 1-naphthyl & $(d, l)-7 \mathbf{b}$ & $46 \mathrm{~h}^{\mathrm{d}}$ & 62 & 32 & tr. \\
4 & “ & meso-7b & $52 \mathrm{~h}^{\mathrm{d}}$ & 59 & 36 & 4 \\
5 & 2-thienyl & $(d, l)-7 \mathrm{c}$ & $22 \mathrm{~h}^{\mathrm{e}}$ & 73 & 15 & 3 \\
6 & “ & meso-7c & $20 \mathrm{~h}^{\mathrm{e}}$ & 68 & 23 & 5 \\
\hline
\end{tabular}

a Reactions in refluxing anhydrous toluene in the presence of DDQ: 4 mol equiv. of DDQ were initially employed, with further addition of reactant being required during reaction to make up its disappearance with time (TLC). ${ }^{b}$ Yields of chromatographically isolated products. ${ }^{c}$ Recovered unreacted substrate. ${ }^{\mathrm{d}}$ Additional DDQ after $12 \mathrm{~h}$ and $24 \mathrm{~h} \mathrm{(2} \mathrm{mol} \mathrm{equiv.} \mathrm{each).} \mathrm{e} \mathrm{Additional}$ DDQ after $12 \mathrm{~h}$ (2 mol equiv.). 


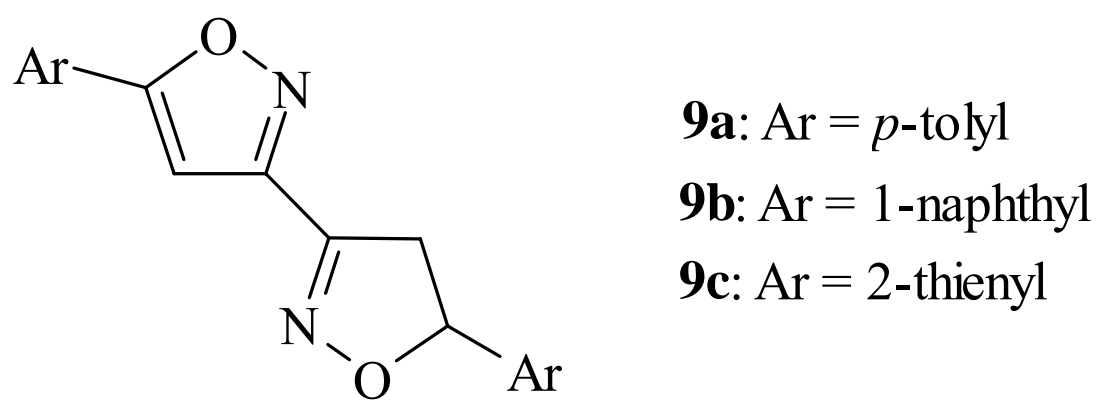

\section{Conclusions}

The reactions of Schemes 3, 5, and 6 represent a novel access to compounds 6, 7, and 8, respectively, characterized by the interesting [3,3']bi-isoxazolyl building block, coupling easy procedures with satisfactory- to excellent yields. The 5 - 6 transformation has furthermore allowed us, on stereochemical grounds, to advance a mechanism for the iodide-catalyzed nitrocyclopropane- to five-membered cyclic nitronate isomerization. Finally, the results of Table 3 show that the aromatization of 7 could also be exploited, thanks to its stepwise nature, for the synthesis of the partially aromatized compounds 9, which in turn represent appealing intermediates.

\section{Experimental Section}

General Procedures. Melting points were determined on a Büchi 535 apparatus and are uncorrected. ${ }^{1} \mathrm{H}$ NMR and ${ }^{13} \mathrm{C}$ NMR spectra were recorded using $\mathrm{CDCl}_{3}$ solutions at 200 and 50 $\mathrm{MHz}$, respectively, with a Varian Gemini 200 spectrometer; TMS was used as internal standard and chemical shifts are reported as $\delta$ values (ppm). Analytical chromatography was performed on a HPLC system comprising a Waters model 510 pump, a Rheodyne model 7725i $20 \mu \mathrm{l}$ injector, and a Jasco model CD $995 \mathrm{UV} / \mathrm{CD}$ detector. Chromatographic data were collected and processed using Millennium 2010 Chromatography Manager software (Waters Chromatography).

Materials. Dioxane was filtered through alumina, refluxed over sodium, distilled and stored over sodium. Dimethyl sulfoxide and toluene (Fluka, stored over molecular sieves) were used as received. $\mathrm{NaI}$ and DDQ were dried $\left(\mathrm{P}_{2} \mathrm{O}_{5}\right)$ under reduced pressure before use. $\mathrm{P}(\mathrm{OMe})_{3}$ was distilled before use. 1,1'-Dinitro-2,2'-diaryl[1,1']bi(cyclopropyl)s (5a-c) were synthesized as previously reported. $2 \mathrm{~b}$ 
Column- or preparative-plate chromatographies were performed on silica gel using petroleum ether (b.p. $40-60{ }^{\circ} \mathrm{C}$ ) and gradients (or appropriate mixtures) with $\mathrm{CH}_{2} \mathrm{Cl}_{2}, \mathrm{Et}_{2} \mathrm{O}$, or EtOAc as eluents, the solvents being distilled before use.

Stereoselective HPLC: Enantio- and diastereo-selective HPLC was performed on "brush-type" chiral columns: $(R, R)$-Whelk-01 (250×4.6 mm I.D.) from Regis Chemical Co. (Morton Groove, IL) using multiple detections: UV and CD (see Figures 1-4).

Isomerization of $1,1^{\prime}$-dinitro-2,2'-diaryl[1,1']bi(cyclopropyl)s (5) to 5,5'-diaryl-4,5,4',5'tetrahydro[3,3']bi-isoxazolyl 2,2'-dioxides (6)

In a flask equipped with an argon inlet and a magnetic stirring bar, a solution of 5 (1 mmol) and dry $\mathrm{NaI}(2 \mathrm{mmol})$ in anhydrous DMSO $(22 \mathrm{ml})$ was heated at $70{ }^{\circ} \mathrm{C}$. At the end of the reaction (as judged by TLC analysis) the mixture was cooled to room temperature and diluted with brine. The precipitated product was then collected by filtration. In the case of the 2-thienyl derivative $5 c$, as the instability of the $(d, l)$ - and meso- diastereomers does not allow a practical separation, $2 \mathrm{~b}$ the reaction was performed on the crude final mixture from the bicyclopropanation; in this case the work-up of the isomerization required extraction with diethyl ether, the extracts then being washed with water and dried over $\mathrm{Na}_{2} \mathrm{SO}_{4}$. After removal of the solvent under reduced pressure a flash-chromatography on silica gel with gradients of petroleum ether (b.p. $40-60{ }^{\circ} \mathrm{C}$ ) and ethyl acetate provided $(d, l)-6 \mathbf{c}$ and meso-6c as pure samples.

5,5'-Bis-(4-methylphenyl)-4,4',5,5'-tetrahydro[3,3']bi-isoxazolyl 2,2'-dioxide (6a). (d,I)-6a. m.p. $177.7-178.1{ }^{\circ} \mathrm{C}$ (ethanol). ${ }^{1} \mathrm{H}$ NMR: $\delta 2.37(6 \mathrm{H}, \mathrm{s}), 3.70(2 \mathrm{H}, \mathrm{dd}, J 8.6$ and $17.0 \mathrm{~Hz}), 4.07$ $(2 \mathrm{H}$, dd, $J 9.4$ and $17.0 \mathrm{~Hz}), 5.72(2 \mathrm{H}$, app. t, $J 8.8 \mathrm{~Hz}), 7.22$ and $7.30(8 \mathrm{H}$ in all, AA'BB' system, $J 8.2 \mathrm{~Hz}) .{ }^{13} \mathrm{C}$ NMR: $\delta 21.20,37.91,78.20,109.67,125.93,129.65,134.20$ and 139.17. Anal. Calcd. for $\mathrm{C}_{20} \mathrm{H}_{20} \mathrm{~N}_{2} \mathrm{O}_{4}$ (352.38): C, 68.17; H, 5.72; N, 7.95. Found: C, 68.04; H, 5.74; N, $7.87 \%$.

meso-6a. m.p. $235.7-236.0{ }^{\circ} \mathrm{C}$ (ethanol / dioxane). ${ }^{1} \mathrm{H}$ NMR: $\delta 2.37$ (6H, s), $3.70(2 \mathrm{H}, \mathrm{dd}, J 8.2$ and $17.2 \mathrm{~Hz}), 4.07(2 \mathrm{H}, \mathrm{dd}, J 9.2$ and $17.2 \mathrm{~Hz}), 5.70(2 \mathrm{H}$, app. t, $J 8.6 \mathrm{~Hz}), 7.23$ and $7.31(8 \mathrm{H}$ in all, AA'BB' system, $J$ 8.1 Hz). ${ }^{13} \mathrm{C}$ NMR: $\delta 21.21,37.93,78.08,109.56,125.84,129.66,134.36$ and 139.14. Anal. Calcd. for $\mathrm{C}_{20} \mathrm{H}_{20} \mathrm{~N}_{2} \mathrm{O}_{4}$ (352.38): C, 68.17; H, 5.72; N, 7.95. Found: C, 67.96; H, 5.66; N, 7.90\%.

5,5'-Bis-(1-naphthyl)-4,4',5,5'-tetrahydro[3,3']bi-isoxazolyl 2,2'-dioxide (6b). (d,l)-6b. m.p. 243.4-244.5 ${ }^{\circ} \mathrm{C}$ (dec.) (methylene chloride / petroleum ether, b.p. $40-60{ }^{\circ} \mathrm{C}$ ). ${ }^{1} \mathrm{H}$ NMR: $\delta 3.79$ $(2 \mathrm{H}, \mathrm{dd}, J 6.6$ and $17.2 \mathrm{~Hz}), 4.37(2 \mathrm{H}, \mathrm{dd}, J 9.9$ and $17.2 \mathrm{~Hz}), 6.46(2 \mathrm{H}$, dd, $J 6.6$ and $9.9 \mathrm{~Hz})$, $7.55(8 \mathrm{H}, \mathrm{m})$ and $7.87(6 \mathrm{H}, \mathrm{m}) .{ }^{13} \mathrm{C}$ NMR: $\delta 37.74,75.42,109.36,122.24,122.31,125.32$, $126.17,126.97,129.28,129.37,133.07$ and 133.96; one quaternary carbon is not detectable. Anal. Calcd. for $\mathrm{C}_{26} \mathrm{H}_{20} \mathrm{~N}_{2} \mathrm{O}_{4}$ (424.45): C, 73.57; H, 4.75; N, 6.60. Found: C, 73.45; H, 4.78; N, $6.50 \%$.

meso-6b. m.p. $222.1-223.1{ }^{\circ} \mathrm{C}$ (dioxane / petroleum ether, b.p. $\left.40-60{ }^{\circ} \mathrm{C}\right) .{ }^{1} \mathrm{H}$ NMR: $\delta 3.84(2 \mathrm{H}$, dd, $J 7.0$ and $17.2 \mathrm{~Hz}), 4.32(2 \mathrm{H}, \mathrm{dd}, J 9.6$ and $17.2 \mathrm{~Hz}), 6.42(2 \mathrm{H}, \mathrm{dd}, J 7.0$ and $9.6 \mathrm{~Hz}), 7.56$ 
$(6 \mathrm{H}, \mathrm{m}), 7.84(8 \mathrm{H}, \mathrm{m}) .{ }^{13} \mathrm{C}$ NMR: $\delta 37.71,75.50,109.42,122.28,122.34,125.33,126.21$, 126.99, 129.31, 129.39, 129.47, 133.11 and 134.02. Anal. Calcd. for $\mathrm{C}_{26} \mathrm{H}_{20} \mathrm{~N}_{2} \mathrm{O}_{4}$ (424.45): C, 73.57; H, 4.75; N, 6.60. Found: C, 73.65; H, 4.70; N, 6.52\%.

5,5'-Bis-(2-thienyl)-4,4',5,5'-tetrahydro[3,3']bi-isoxazolyl 2,2'-dioxide (6c). (d,l)-6c. m.p. 136.0-137.1 ${ }^{\circ} \mathrm{C}$ (toluene / petroleum ether, b.p. 40-60 $\left.{ }^{\circ} \mathrm{C}\right) .{ }^{1} \mathrm{H}$ NMR: $\delta 3.85(2 \mathrm{H}, \mathrm{dd}, J 8.0$ and $17.2 \mathrm{~Hz}), 4.10(2 \mathrm{H}, \mathrm{dd}, J 9.2$ and $17.2 \mathrm{~Hz}), 5.98(2 \mathrm{H}$, app. t, $J 8.4 \mathrm{~Hz}), 7.04(2 \mathrm{H}, \mathrm{dd}, J 3.6$ and $5.0 \mathrm{~Hz}), 7.19(2 \mathrm{H}$, br. d, $J 3.6 \mathrm{~Hz})$ and $7.40(2 \mathrm{H}, \mathrm{dd}, J 1.2$ and $5.0 \mathrm{~Hz}) .{ }^{13} \mathrm{C} \mathrm{NMR}: \delta 37.84$, $74.38,109.43,127.23$ and 139.24; only two of the four expected $\mathrm{CH}$ signals are detectable, at $\delta$ 74.38 and 127.23 , with an intensity ratio of about 1:3. Evidently, the three thiophenic $\mathrm{CH}$ resonate at the same $\delta(127.23)$ : c.f. the ${ }^{13} \mathrm{C}$ NMR spectrum of the meso-isomer. Anal. Calcd. for $\mathrm{C}_{14} \mathrm{H}_{12} \mathrm{~N}_{2} \mathrm{O}_{4} \mathrm{~S}_{2}$ (336.39): C, 49.99; H, 3.60; N, 8.33. Found: C, 50.10; H, 3.52; N, 8.39\%.

meso-6c. m.p. $182.9-184.1{ }^{\circ} \mathrm{C}$ (toluene / petroleum ether, b.p. $40-60{ }^{\circ} \mathrm{C}$ ). ${ }^{1} \mathrm{H} \mathrm{NMR}$ : the spectrum is perfectly superimposable to that of the $(d, l)$ isomer: accordingly, the spectrum of a mixture of the two isomers is characterized by only one series of signals. ${ }^{13} \mathrm{C}$ NMR: $\delta 37.89$, 74.34, 109.39, 127.14, 127.17, 127.25\%. and 139.40. Anal. Calcd. for $\mathrm{C}_{14} \mathrm{H}_{12} \mathrm{~N}_{2} \mathrm{O}_{4} \mathrm{~S}_{2}(336.39)$ : C, 49.99; H, 3.60; N, 8.33. Found: C, 50.18; H, 3.60; N, 8.23\%.

\section{Reduction of 5,5'-diaryl-4,5,4',5'-tetrahydro[3,3']bi-isoxazolyl 2,2'-dioxides (6) to} 5,5'-diaryl-4,5,4',5'-tetrahydro[3,3']bi-isoxazolyls (7) ${ }^{6 e, 14 .}$

In a flame-dried two-neck flask equipped with a reflux condenser surmounted by an argon inlet, a rubber septum and a magnetic stirring-bar, trimethyl phosphite $(40 \mathrm{mmol})$ was added to a warm solution of 6 ( $1 \mathrm{mmol})$ in anhydrous dioxane $(28 \mathrm{ml})$ and the reaction mixture heated to reflux under argon (17-24 h). After cooling, the solvent and the excess $\mathrm{P}(\mathrm{OMe})_{3}$ were removed under reduced pressure, and the solid residue taken up with petroleum ether (b.p. $40-60{ }^{\circ} \mathrm{C}$ ) and methylene chloride. In the case of $(d, l)-7 c$, the residue did not solidify and was purified by column chromatography.

5,5'-Bis-(4-methylphenyl)-4,4',5,5'-tetrahydro[3,3']bi-isoxazolyl (7a). (d,I)-7a. m.p. 82.3$83.1^{\circ} \mathrm{C}$ (petroleum ether, b.p. $40-60{ }^{\circ} \mathrm{C}$ ). ${ }^{1} \mathrm{H}$ NMR: $\delta 2.36(6 \mathrm{H}, \mathrm{s}), 3.33(2 \mathrm{H}, \mathrm{dd}, J 9.0$ and $17.2 \mathrm{~Hz}), 3.72(2 \mathrm{H}, \mathrm{dd}, J 11.0$ and $17.2 \mathrm{~Hz}), 5.72(2 \mathrm{H}, \mathrm{dd}, J 9.0$ and $11.0 \mathrm{~Hz})$ and $7.22(8 \mathrm{H}$, AA'BB' system, $J 8.4 \mathrm{~Hz}) .{ }^{13} \mathrm{C}$ NMR: $\delta 21.18,41.40,83.97,126.01,129.50,136.73,138.44$ and 150.87. Anal. Calcd. for $\mathrm{C}_{20} \mathrm{H}_{20} \mathrm{~N}_{2} \mathrm{O}_{2}$ (320.39): C 74.98; H, 6.29; N, 8.74. Found: C, 74.45; H, $6.16 ; \mathrm{N}, 8.65 \%$.

meso-7a. m.p. $187.6-188.3{ }^{\circ} \mathrm{C}$ (ethanol). ${ }^{1} \mathrm{H}$ NMR: $\delta 2.36(6 \mathrm{H}, \mathrm{s}), 3.33(2 \mathrm{H}$, dd, $J 8.8$ and 17.2 $\mathrm{Hz}), 3.72(2 \mathrm{H}, \mathrm{dd}, J 11.2$ and $17.2 \mathrm{~Hz}), 5.71(2 \mathrm{H}, \mathrm{dd}, J 8.8$ and $11.2 \mathrm{~Hz})$ and $7.22\left(8 \mathrm{H}, \mathrm{AA}^{\prime} \mathrm{BB}^{\prime}\right.$ system, $J$ 8.4 Hz). ${ }^{13} \mathrm{C}$ NMR: $\delta 21.17,41.39$, 83.96, 125.98, 129.51, 136.79, 138.45 and 150.89. Anal. Calcd. for $\mathrm{C}_{20} \mathrm{H}_{20} \mathrm{~N}_{2} \mathrm{O}_{2}$ (320.39): C 74.98; H, 6.29; N, 8.74. Found: C, 74.41; H, 6.34; N, $8.36 \%$.

5, 5'-Bis-(1-naphthyl)-4,4',5,5'-tetrahydro[3,3']bi-isoxazolyl (7b). (d,I)-7b. m.p. 144.3$145.8^{\circ} \mathrm{C}$ (petroleum ether, b.p. $80-100{ }^{\circ} \mathrm{C}$ ). ${ }^{1} \mathrm{H}$ NMR: $\delta 3.41(2 \mathrm{H}, \mathrm{dd}, J 8.0$ and $17.0 \mathrm{~Hz}), 4.01$ $(2 \mathrm{H}, \mathrm{dd}, J 11.4$ and $17.0 \mathrm{~Hz}), 6.45(2 \mathrm{H}, \mathrm{dd}, J 8.0$ and $11.4 \mathrm{~Hz}), 7.50(8 \mathrm{H}, \mathrm{m})$ and $7.87(6 \mathrm{H}, \mathrm{m})$. 
${ }^{13} \mathrm{C}$ NMR: $\delta$ 41.50, 81.56, 122.57, 122.81, 125.39, 125.92, 126.56, 128.82, 129.14, 129.64, 133.97, 135.14 and 151.07. Anal. Calcd. for $\mathrm{C}_{26} \mathrm{H}_{20} \mathrm{~N}_{2} \mathrm{O}_{2}$ (392.45): C, 79.57; H, 5.14; N, 7.14. Found: C, 79.51; H, 4.99; N, 7.11\%.

meso-7b. m.p. $283.5-285.0{ }^{\circ} \mathrm{C}$ (dec.) (dioxane). ${ }^{1} \mathrm{H}$ NMR: $\delta 3.44(2 \mathrm{H}$, dd, $J 8.3$ and $17.2 \mathrm{~Hz}$ ), $3.98(2 \mathrm{H}, \mathrm{dd}, J 11.2$ and $17.2 \mathrm{~Hz}), 6.42(2 \mathrm{H}, \mathrm{dd}, J 8.3$ and $11.2 \mathrm{~Hz}), 7.56(8 \mathrm{H}, \mathrm{m})$ and $7.89(6 \mathrm{H}$, m). ${ }^{13} \mathrm{C}$ NMR: $\delta 41.43,81.66,122.65,122.82,125.39,125.93,126.57,128.89,129.16,129.70$, 134.00, 135.11 and 151.12. Anal. Calcd. for $\mathrm{C}_{26} \mathrm{H}_{20} \mathrm{~N}_{2} \mathrm{O}_{2}$ (392.45): C, 79.57; H, 5.14; N, 7.14. Found: C, 79.21; H, 4.96; N, 7.15\%.

5,5'-Bis-(2-thienyl)-4,4',5,5'-tetrahydro[3,3']bi-isoxazolyl (7c). (d,I)-7c. m.p. 90.8-92.0 ${ }^{\circ} \mathrm{C}$ (petroleum ether, b.p. $\left.80-100{ }^{\circ} \mathrm{C}\right) .{ }^{1} \mathrm{H}$ NMR: $\delta 3.48(2 \mathrm{H}$, dd, $J 8.8$ and $17.4 \mathrm{~Hz}), 3.74(2 \mathrm{H}, \mathrm{dd}, J$ 10.6 and $17.4 \mathrm{~Hz}), 5.98(2 \mathrm{H}$, dd, $J 8.8$ and $10.6 \mathrm{~Hz}), 7.01(2 \mathrm{H}, \mathrm{dd}, J 3.6$ and $5.0 \mathrm{~Hz}), 7.11(2 \mathrm{H}$, br. d, $J 3.6 \mathrm{~Hz})$ and $7.34(2 \mathrm{H}, \mathrm{dd}, J 1.2$ and $5.0 \mathrm{~Hz}) .{ }^{13} \mathrm{C} \mathrm{NMR}: \delta 41.26,79.82,126.01,126.32$, 127.06, 142.04 and 150.79. Anal. Calcd. for $\mathrm{C}_{14} \mathrm{H}_{12} \mathrm{~N}_{2} \mathrm{O}_{2} \mathrm{~S}_{2}$ (304.39): C, 55.24; H, 3.97; N, 9.20\%. Found: C, 54.98; H, 3.91; N, 9.23\%.

meso-7c. m.p. $158.8-159.8{ }^{\circ} \mathrm{C}$ (ethanol). ${ }^{1} \mathrm{H}$ NMR: $\delta 3.48(2 \mathrm{H}, \mathrm{dd}, J 8.3$ and $17.4 \mathrm{~Hz}), 3.75(2 \mathrm{H}$, $\mathrm{dd}, J 10.7$ and $17.4 \mathrm{~Hz}), 5.98(2 \mathrm{H}, \mathrm{dd}, J 8.3$ and $10.7 \mathrm{~Hz}), 7.01(2 \mathrm{H}, \mathrm{dd}, J 3.8$ and $5.0 \mathrm{~Hz}), 7.11$ $(2 \mathrm{H}$, br. d, $J 3.8 \mathrm{~Hz})$ and $7.34(2 \mathrm{H}$, dd, $J 1.3$ and $5.0 \mathrm{~Hz}) .{ }^{13} \mathrm{C}$ NMR: $\delta 41.31,79.80,125.99$, 126.30, 127.06, 142.19 and 150.79. Anal. Calcd. for $\mathrm{C}_{14} \mathrm{H}_{12} \mathrm{~N}_{2} \mathrm{O}_{2} \mathrm{~S}_{2}$ (304.39): C, 55.24; $\mathrm{H}$, 3.97;

N, 9.20\%. Found: C, 55.20; H, 3.91; N, 9.15\%.

\section{Aromatization of 5,5'-diaryl-4,5,4',5'-tetrahydro[3,3']bi-isoxazolyls (7) to 5,5'-diaryl[3,3']bi- isoxazolyls (8).}

In a two-necked flask, equipped with a reflux condenser surmounted by an argon inlet, a rubber septum and a magnetic stirring-bar, DDQ $(1.2 \mathrm{mmol})$ was added to a solution of 7 (0.3 mmol) in $11 \mathrm{ml}$ of dry toluene. The mixture was kept under argon and heated at reflux following the disappearance of 7 by TLC. Further additions of DDQ $(0.3$ or $0.6 \mathrm{mmol})$ were needed in order to obviate to its disappearance (TLC) due to decomposition in the conditions employed. Work-up of the final mixture involved filtration and careful washing of the solid with toluene and abundant $\mathrm{CH}_{2} \mathrm{Cl}_{2}$. After drying $\left(\mathrm{Na}_{2} \mathrm{SO}_{4}\right)$ and rotary-evaporation of the solvent, a column chromatography on silica gel yielded pure $\mathbf{8}$ and $\mathbf{9}$, together with some unreacted substrate.

5,5'-Bis-(4-methylphenyl)[3,3']bi-isoxazolyl (8a). m.p. 250.2-251.3 ${ }^{\circ} \mathrm{C}$ (ethanol / dioxane) [Lit. ${ }^{15} 251-253{ }^{\circ} \mathrm{C}$ (ethanol)]. ${ }^{1} \mathrm{H}$ NMR: $\delta 2.43(6 \mathrm{H}, \mathrm{s}), 7.03(2 \mathrm{H}, \mathrm{s}), 7.31$ and 7.75 (4H each, AA'BB' system, $J 8.0 \mathrm{~Hz}) .{ }^{13} \mathrm{C}$ NMR: $\delta 21.55,97.12,124.26,125.91,129.79,141.00,154.94$ and 171.21 .

5,5'-Bis-(1-naphthyl)[3,3']bi-isoxazolyl (8b). m.p. $171.0-171.8{ }^{\circ} \mathrm{C}$ (toluene / petroleum ether, b.p. $\left.80-100{ }^{\circ} \mathrm{C}\right) .{ }^{1} \mathrm{H}$ NMR: $\delta 7.26(2 \mathrm{H}, \mathrm{s}), 7.62(6 \mathrm{H}, \mathrm{m}), 7.98(6 \mathrm{H}, \mathrm{m})$ and $8.39(2 \mathrm{H}, \mathrm{m}) .{ }^{13} \mathrm{C}$ NMR: $\delta 101.87,124.56,124.85,125.21,126.63,127.69,127.98,128.82,130.28,131.38$, 133.85, 154.85 and 171.18. Anal. Calcd. for $\mathrm{C}_{26} \mathrm{H}_{16} \mathrm{~N}_{2} \mathrm{O}_{2}$ (388.42): C, 80.40; H, 4.15; N, 7.21\%.

Found: C, 80.11; H, 4.22; N, 7.12\%. 
5,5'-Bis-(2-thienyl)[3,3']bi-isoxazolyl (8c). m.p. 239.2-240.6 ${ }^{\circ} \mathrm{C}$ (ethanol). ${ }^{1} \mathrm{H}$ NMR: $\delta 6.94$ $(2 \mathrm{H}, \mathrm{s}), 7.17(2 \mathrm{H}, \mathrm{dd}, J 3.7$ and $5.0 \mathrm{~Hz}), 7.51(2 \mathrm{H}, \mathrm{dd}, J 1.2$ and $5.0 \mathrm{~Hz})$ and $7.60(2 \mathrm{H}, \mathrm{dd}, J 1.2$ and $3.7 \mathrm{~Hz}) .{ }^{13} \mathrm{C}$ NMR: $\delta$ 97.40, 127.65, 128.23, 128.65, 154.74 and 166.12; one quaternary carbon is not detectable. Anal. Calcd. for $\mathrm{C}_{14} \mathrm{H}_{8} \mathrm{~N}_{2} \mathrm{O}_{2} \mathrm{~S}_{2}(300.36)$ : C 55.98, H 2.68, N, 9.33\%. Found: C, 56.12; H, 2.59; N, 9.28\%.

5,5'-Bis-(p-tolyl)-4,5-dihydro[3,3']bi-isoxazolyl (9a). The small quantities isolated in mixed chromatographic fractions did not allow a purification matching analytical standards; on the other hand, the NMR spectra could be easily deduced from a sample containing traces of $8 \mathbf{a a} .1 \mathrm{H}$ NMR: $\delta 2.36(3 \mathrm{H}, \mathrm{s}), 2.42(3 \mathrm{H}, \mathrm{s}), 3.45(1 \mathrm{H}, \mathrm{dd}, J 8.8$ and $17.3 \mathrm{~Hz}), 3.84(1 \mathrm{H}, \mathrm{dd}, J 11.1$ and $17.3 \mathrm{~Hz}), 5.77(1 \mathrm{H}, \mathrm{dd}, J 8.8$ and $11.1 \mathrm{~Hz}), 6.94(1 \mathrm{H}, \mathrm{s}), 7.20(2 \mathrm{H}$, half of AA'BB' system, $J 8.0$ $\mathrm{Hz}), 7.29$ (4H, two halves AA'BB' systems partially overlapped) and 7.70 (2H, half of AA'BB' system, $J$ 8.2 Hz). 13C NMR: $\delta$ 21.18, 21.53, 41.73, 83.67, 96.87, 124.17, 125.90, 126.02, $129.52,129.79,136.92,138.42,141.02,149.53,155.82$ and 170.85 .

5,5'-Bis-(1-naphthyl)-4,5-dihydro[3,3']bi-isoxazolyl (9b). m.p. 158.2-159.8 ${ }^{\circ} \mathrm{C}$ (toluene / petroleum ether, b.p. $\left.80-100{ }^{\circ} \mathrm{C}\right) .1 \mathrm{H} \mathrm{NMR}: \delta 3.59(1 \mathrm{H}, \mathrm{dd}, J 8.0$ and $17.2 \mathrm{~Hz}), 4.15(1 \mathrm{H}$, dd, $J$ 11.4 and $17.2 \mathrm{~Hz}), 6.54(1 \mathrm{H}, \mathrm{dd}, J 8.0$ and $11.4 \mathrm{~Hz}), 7.14(1 \mathrm{H}, \mathrm{s}), 7.60(7 \mathrm{H}, \mathrm{m}), 7.95(6 \mathrm{H}, \mathrm{m})$ and 8.30 (1H, m). 13C NMR: $\delta 41.85,81.38,101.57,122.80,122.87,124.44,124.75,125.13,125.44$, $125.92,126.58,127.61,127.88,128.77,128.88,129.17,129.72,130.22,131.31,133.78,134.02$, 135.24, 149.88, 155.59 and 170.69. Anal. Calcd. for $\mathrm{C} 26 \mathrm{H} 18 \mathrm{~N} 2 \mathrm{O} 2$ (390.43): C, 79.98; H, 4.65; N, 7.17\%. Found: C, 79.91; H, 4.48; N, 7.12\%.

5,5'-Bis-(2-thienyl)-4,5-dihydro[3,3']bi-isoxazolyl (9c). m.p. $134.8-136.3^{\circ} \mathrm{C}$ (petroleum ether, b.p. $\left.80-100^{\circ} \mathrm{C}\right) .1 \mathrm{H} \mathrm{NMR}: \delta 3.59(1 \mathrm{H}, \mathrm{dd}, J 8.6$ and $17.4 \mathrm{~Hz}), 3.86(1 \mathrm{H}, \mathrm{dd}, J 10.6$ and $17.4 \mathrm{~Hz})$, $6.03(1 \mathrm{H}, \mathrm{dd}, J 8.6$ and $10.6 \mathrm{~Hz}), 6.85(1 \mathrm{H}, \mathrm{s}), 7.02(1 \mathrm{H}, \mathrm{dd}, J 3.6$ and $5.2 \mathrm{~Hz}), 7.15(2 \mathrm{H}, \mathrm{m})$, $7.34(1 \mathrm{H}, \mathrm{dd}, J 1.1$ and $5.2 \mathrm{~Hz}), 7.50(1 \mathrm{H}, \mathrm{dd}, J 1.1$ and $5.2 \mathrm{~Hz})$ and $7.57(1 \mathrm{H}, \mathrm{dd}, J 1.1$ and 3.6 Hz). ). 13C NMR: $\delta 41.65,79.49,97.12,125.96,126.27,127.06,127.64,128.21,128.49,128.65$, 142.29, 149.35, 155.68 and 165.76. Anal. Calcd. for $\mathrm{C} 14 \mathrm{H} 10 \mathrm{~N} 2 \mathrm{O} 2 \mathrm{~S} 2$ (302.37): C, 55.61; H, 3.33; N, 9.26\%. Found: C, 55.38; H, 3.21; N, 9.20\%.

\section{Acknowledgements}

Financial support was provided by Ministero dell'Istruzione, dell'Università e della Ricerca (MIUR, PRIN-2001). F. G. acknowledges the financial support from University "La Sapienza" (Ricerche di Ateneo 2001-2003) and from Consiglio Nazionale delle Ricerche (Italy). We thank Miss Tiziana Armaroli for skillful technical assistance. 


\section{References}

1. Synthetic exploitation of the ring-opening of nitrothiophenes, part XIV. For part XIII see Ref. 2a.

2. (a) Bianchi, L.; Dell'Erba, C.; Gabellini, A.; Novi, M.; Petrillo, G.; Tavani, C. Tetrahedron 2002, 58, 3379. (b) Armaroli, T.; Dell'Erba, C.; Gabellini, A.; Gasparrini, F.; Mugnoli, A.; Novi, M.; Petrillo, G.; Tavani, C. Eur. J. Org. Chem. 2002, 1284. (c) Dell'Erba, C.; Gabellini, A.; Mugnoli, A.; Novi, M.; Petrillo, G.; Tavani, C. Tetrahedron 2001, 57, 9025. (d) Dell'Erba, C.; Gabellini, A.; Novi, M.; Petrillo, G.; Tavani, C.; Cosimelli, B.; Spinelli, D. Tetrahedron 2001, 57, 8159. (e) Dell'Erba, C.; Mugnoli, A.; Novi, M.; Pani, M.; Petrillo, G.; Tavani, C. Eur. J. Org. Chem. 2000, 903. (f) Dell'Erba, C.; Mugnoli, A.; Novi, M.; Pertici, M.; Petrillo, G.; Tavani, C. Eur. J. Org. Chem. 1999, 431. (g) For a survey of relevant earlier literature see: Spinelli, D.; Consiglio, G.; Dell'Erba, C.; Novi, M. In The Chemistry of Heterocyclic Compounds, Thiophene ad its Derivatives, Gronowitz, S., Ed.; J. Wiley: New York, 1991; Vol. 44, pp 295-396. Dell'Erba, C.; Novi, M.; Petrillo, G.; Tavani, C. In Topics in Heterocyclic Systems: Synthesis, Reactions and Properties, Attanasi, O. A.; Spinelli, D., Eds.; Research Signpost: Trivandrum, India, 1996; Vol. 1, pp 1-12. Consiglio, G.; Spinelli, D.; Dell'Erba, C.; Novi, M.; Petrillo, G. Gazz. Chim. Ital. 1997, 127, 753.

3. (a) O'Bannon, P. E.; Daley, W. P. Tetrahedron 1990, 46, 7341. (b) Seebach, D.; Häner, R.; Vettiger, T. Helv. Chim. Acta 1987, 70, 1507. (c) Vettiger, T.; Seebach, D. Ann. Chem. 1990, 112, 195. (d) van Velzen, J. C.; Kruk, C.; Spaargaren, K.; de Boer, Th. J. Rec. Trav. Chim. 1972, 91, 557. (e) van Velzen, J. C.; Kruk, C.; de Boer, Th. J. Rec. Trav. Chim. 1971, 90,842 .

4. (a) Johnson, C. R.; Lockard, J. P.; Kennedy, E. R. J. Org. Chem. 1980, 45, 264. (b) Kaji, E.; Zen, S. Chem. Pharm. Bull. 1980, 28, 479. (c) Kaji, E.; Ichikawa, H.; Zen, S. Bull. Chem. Soc. Jpn. 1979, 52, 2928. (d) Kohler, B. J. Am. Chem. Soc. 1924, 46, 2105.

5. (a) Papadopoulou, M. V.; Litinas, K. E.; Nicolaides, D. N. J. Heterocycl. Chem. 1987, 24, 337 and references therein. (b) Cramer, R. D.; McClellan, W. R. J. Org. Chem. 1961, 26, 2976. (c) Gaudiano, G.; Ricca, A. Gazz. Chim. Ital. 1959, 89, 587. See also: Samuelson, R. E.; Miller, R. B.; Kurth, M. J. J. Org. Chem. 2000, 65, 2225.

6. For leading recent references on the five-membered cyclic nitronates see: (a) Breuer, E. Nitrones and Nitronic Acid Derivatives: Their Structure and Their Use in Synthesis. In The chemistry of Amino, Nitroso, and Nitro Compounds and Their Derivatives; Patai, S. Ed.; John Wiley and Sons: New York, 1982; pp 544-546. (b) Torssell, K. B. G. Nitrile Oxides, Nitrones and Nitronates in Organic Synthesis; VCH Publishers: New York, 1988; pp 110111. (c) Tartakovskii, V. A. Izv. Akad. Nauk SSSR, Ser. Khim. (Engl. Transl.) 1984, 147. (d) Shipchandler, M. T. Synthesis 1979, 666. (e) Rosini, G.; Marotta, E.; Righi, P.; Seerden, J. P. J. Org. Chem. 1991, 56, 6258. (f) Denmark, S. E.; Moon, Y.-C.; Senanayake, C. B. W. J. Am. Chem. Soc. 1990, 112, 311. (g) Chow, Y. L.; Shu, Y. Y.; Bakker, B. H.; Pillay, K. S. 
Heterocycles 1989, 29, 2245. (h) Brook, M. A.; Seebach, D. Can. J. Chem. 1987, 65, 836. (i) Righi, P.; Marotta, E.; Landuzzi, A.; Rosini, G. J. Am. Chem. Soc. 1996, $118,9446$.

7. For leading recent references on isoxazolines see: (a) Padwa, A. Comprehensive Organic Synthesis; Trost, B. M.; Fleming, I., Eds.; Pergamon: Oxford, 1991; Vol. 4, p 1069. (b) Sainsbury, M. Comprehensive Organic Synthesis; Trost, B. M.; Fleming, I., Eds.; Pergamon: Oxford, 1991; Vol. 8, pp 646-648. (c) Curran, D. P. Advances in Cycloadditions; Curran, D. P., Ed.; JAI Press: Greenwich, CT, 1988; Vol. 1, pp. 129-189. (d) Padwa, A.; Schoffstall, A. M. Advances in Cycloadditions; Curran, D. P., Ed.; JAI Press: Greenwich, CT, 1988; Vol. 2, pp. 28-46. (e) Kozikowski, A. P. Acc. Chem. Res. 1984, 17, 410. (f) Jäger, V.; Müller, I. Tetrahedron 1985, 41, 3519. (g) Jager, V.; Schohe, R. Tetrahedron 1984, 40, 2199.

8. For leading recent references on isoxazoles see: (a) Pevarello, P.; Amici, R.; Brasca, M. G.; Villa, M.; Varasi, M. Recent Applications of the Isoxazole Ring in Medicinal Chemistry, In Targets in Heterocyclic Systems; Attanasi, O. A.; Spinelli, D., Eds.; Italian Society of Chemistry: Rome; Vol. 3, 1999, pp 301-339. (b) Grünanger, P.; Vita Finzi, P. Isoxazole: Part 1, In The Chemistry of Heterocyclic Compounds, Taylor, E. C.; Weissberger, A., Eds.; Wiley: New York, 1990. (c) Grünanger, P.; Vita Finzi, P. Isoxazole: Part 2, In The Chemistry of Heterocyclic Compounds, Taylor, E. C.; Weissberger, A., Eds.; Wiley: New York, 1999. (d) Lang, S. A., Jr.; Lin, Y.-i Isoxazoles and their Benzo Derivatives, In Comprehensive Heterocyclic Chemistry, Katritzky, A. R.; Rees, C. W.; Potts, K. T., Eds.; Vol. 6, 1984; pp 1-130. (e) De Luca, L.; Giacomelli, G.; Riu, A. J. Org. Chem. 2001, 66, 6823. (f) Banerjee, A. K.; Bandyopadhyay, S.; Gayen, A. K.; Sengupta, T.; Das, A. K.; Chatterjee, G. K.; Chaudhuri, S. K. Arzneim. Forsch. Drug Res. 1994, 44, 863.

9. (a) Tatee, T.; Kurashige, S.; Shiozaua, A.; Narita, K.; Takei, M.; Ito, S.; Miyazaki, H.; Yamanaka, H.; Mizugaki, M.; Sakamoto, T.; Fukuda, H. Chem. Pharm. Bull. 1986, 34, 1634. (b) Krogsgaard-Larsen, P. Med. Res. Rev. 1988, 8, 27. (c) Sutharchanadevi, M.; Murugan, R. Comp. Heterocycl. Chem., $2^{\text {nd }}$ Edn; Elseiver: Oxford, 1996, Vol. 3; p 221.

10. (a) Müller, R.; Leibold, T.; Pätzel, M.; Jäger, V. Angew. Chem., Int. Ed Engl. 1994, 33, 1295. Kamimura, A. J. Syn. Org. Synth., Jpn. 1992, 50, 808. Kanemasa, S.; Tsuge, O. Heterocycles 1990, 30, 719. (b) Baraldi, P. G.; Barco, A.; Benetti, S.; Pollini, G. P.; Simoni, D. Synthesis 1987, 857. Reiter, L. A. J. Org. Chem. 1987, 52, 2714. (c) Ciller, J. A.; Martin, N.; Seoane, C.; Soto, J. L. J. Chem. Soc., Perkin Trans. 1 1985, 2581. (d) Wakefield, B. J.; Wright, D. J. Adv. Heterocycl. Chem. 1979, 25, 147. (e) Lipshutz, B. H. Chem. Rev. 1986, 86, 795. (f) Kashima, C. Heterocycles 1979, 12, 1343. (g) Nisniwaki, T. Synthesis 1975, 20.

11. Dell'Erba, C.; Novi, M.; Petrillo, G.; Stagnaro, P. J. Heterocyclic Chem. 1994, $31,861$.

12. (a) Newman, H.; Angier, R. B. Tetrahedron 1970, 26, 825. (b) Parker, R. E.; Isaacs, N. S. Chem. Rev. 1959, 59, 737.

13. Bianchi, G.; De Amici, M. J. Chem. Res. (S) 1979, 311.

14. (a) Mélot, J.-M.; Texier-Boullet, F.; Foucaud, A. Synthesis 1988, 558. (b) Marotta, E.; Baravelli, M.; Maini, L.; Righi, P.; Rosini, G. J. Org. Chem. 1998, 63, 8235. 
15. Quilico, A.; Gaudiano, G.; Ricca, A. Gazz. Chim. Ital. 1957, 87, 638. 